\title{
Sebaran dan Struktur Komunitas Moluska di Pantai Mertasari Kota Denpasar, Provinsi Bali
}

\author{
Ni Komang Ayu Sukawati a*, I Wayan Restu a, Suprabadevi Ayumayasari Saraswati a \\ aProgram Studi Manajemen Sumberdaya Perairan, Fakultas Kelautan dan Perikanan, Universitas Udayana, Jimbaran, Badung, \\ Bali-Indonesia \\ *Penulis koresponden. Tel.: +6285-792-486-494 \\ Alamat e-mail: sukawatiayu@gmail.com
}

Diterima (received) 6 Juni 2017; disetujui (accepted) 29 Agustus 2017; tersedia secara online (available online) 30 Agustus 2017

\begin{abstract}
The research objectives were to investigate the distribution and molluscs community structure in Mertasari beach, Denpasar-Bali. The research area was divided into 2 sites, the first site (I) has sandy substrate and second site (II) has muddy sand substrate. This research used quadrat transects systematic sampling method with $1 \times 1 \mathrm{~m}^{2}$ quadrat. The data of the research were analyzed used Microsoft Excel. It was conducted from January to March 2017. The research result shows that the structure of molluscs in Mertasari Beach was support by 31 species richness of 25 species from gastropods and 6 species of bivalves. The density number of the molluscs was $124.5 \mathrm{ind} / \mathrm{m}^{2}$. The diversity index of the molluscs ranged from 2.29 to 2.58 were category as moderate diversity, the evenness index ranged 0.83 to 0.87 were category as high evenness, the dominance index ranged from 0.09-0.13 were category as low. the index number indicates that the ecological condition at Mertasari beach was in good condition so it is suitable to support the molluscs community livelihood. Which was supported by water quality value of dissolved oxygen at Mertasari beach ranged from 4-6.7 mg/l, $\mathrm{pH}$ waters ranged from 7.39-7.74, water temperature ranged from $25.9-29^{\circ} \mathrm{C}$, water salinity ranged from 9-29 ppt. The distribution pattern of 31 species of molluscs were in groups (Id $>1)$.
\end{abstract}

Keywords: Molluscs; Distribution; Structure Community; Mertasari Beach

\begin{abstract}
Abstrak
Penelitian ini bertujuan untuk mengetahui sebaran dan struktur komunitas moluska di perairan Pantai Mertasari Kota Denpasar Provinsi Bali. Lokasi penelitian dibagi menjadi 2 stasiun penelitian, tipe substrat pada stasiun I memiliki tipe substrat berpasir dan tipe substrat pada stasiun II yaitu lumpur berpasir. Penelitian ini menggunakan metode transek kuadrat sistematik sampling dengan kuadrat $1 \times 1 \mathrm{~m}^{2}$. Data hasil penelitian dianalisis menggunakan microsoft excel. Penelitian dilakukan dari bulan Januari-Maret 2017. Hasil penelitian menunjukkan struktur komunitas moluska di perairan Pantai Mertasari didukung dengan kekayaan jenis sebanyak 31 jenis yang terdiri dari 25 jenis dari kelas gastropoda dan 6 jenis dari kelas bivalvia. Nilai kelimpahan jenis moluska di pantai mertasari yaitu 124.5 individu $/ \mathrm{m}^{2}$. Nilai keanekaragaman jenis moluska berkisar 2.29-2.58 tergolong kategori keanekaragaman sedang, nilai indeks keseragaman berkisar 0.83-0.87 tergolong kategori keseragaman tinggi, nilai indeks dominansi berkisar 0.090.13 tergolong kategori dominansi rendah. Nilai tersebut menunjukkan bahwa kondisi ekologi di Pantai Mertasari dalam keadaan baik sehingga mendukung kehidupan komunitas moluska yang didukung dengan nilai kualitas air dimana nilai oksigen terlarut di pantai mertasari berkisar 4-6.7 mg/l, pH perairan berkisar 7.39-7.74, suhu perairan berkisar $25.9-29^{\circ} \mathrm{C}$, salinitas perairan berkisar 9-29 ppt. Pola sebaran 31 jenis moluska yaitu mengelompok (Id $\left.>1\right)$.
\end{abstract}

Kata Kunci: Moluska; Sebaran; Struktur Komunitas; Pantai Mertasari

\section{Pendahuluan}

Kota Denpasar memiliki panjang pantai $36,5 \mathrm{~km}$, beberapa pantai yang terdapat di Kota Denpasar yaitu Pantai Karang, Pantai Batu Jimbar, Pantai Sanur, Pantai Semawang, dan Pantai Mertasari. Pantai Mertasari adalah pantai yang telah mengalami peremajaan melalui proyek 
pengamanan pantai pada tahun 2005 dengan teknik pengisian pasir (sand nourishment) dan krib (groin).

Pantai Mertasari memiliki potensi sumberdaya alam yang melimpah seperti mangrove, lamun, terumbu karang dan biota perairan lainnya. Berdasarkan data Badan Lingkungan Hidup Kota Denpasar (BLH Kota Denpasar, 2015), Pantai Mertasari mempunyai lebar kurang lebih 900 m. Tipe substrat dasar perairan adalah lumpur berpasir, pasir bercampur pecahan karang, sehingga cukup banyak jenis moluska yang dapat hidup di Pantai Mertasari tersebut.

Pantai Mertasari saat ini dilakukan pengembangan kawasan pariwisata dan dilakukan pembangunan dermaga kapal, dan penggunaan lahan pantai dominan adalah kafe dan pangkalan perahu nelayan. Padatnya aktivitas manusia seperti renang, wind surfing, banana boat dan memancing mengakibatkan terjadinya perubahan kondisi ekologi di Pantai Mertasari. Perubahan tersebut berupa menurunnya kualitas perairan dan gangguan kehidupan organisme perairan, seperti moluska.

Moluska merupakan salah satu penyusun ekosistem laut yang mempunyai keanekaragaman spesies tinggi dan menyebar di berbagai habitat laut. Kehidupan moluska secara umum dipengaruhi oleh kualitas perairannya, antara lain jenis substrat, habitat, kekeruhan, $\mathrm{pH}$, suhu, salinitas, kandungan oksigen terlarut dan polutan (Pratiwi dan Ernawati, 2016). Moluska dapat ditemukan di daerah pinggiran pantai hingga laut dalam, moluska menempati daerah terumbu karang, sebagian membenamkan diri dalam sedimen dan beberapa dapat ditemukan menempel pada tumbuhan laut. Moluska dapat hidup pada berbagai substrat, baik substrat berpasir, berbatu dan berlumpur. Moluska memiliki daya adaptasi tinggi terhadap tempat dan cuaca (Cappenberg, 2016).

Moluska merupakan hewan yang dapat digunakan sebagai indikator kualitas perairan karena sifat hidupnya yang relatif menetap untuk jangka waktu panjang sehingga keberadaannya memungkinkan untuk mengetahui kualitas lingkungan. Oleh karena itu, moluska dapat memberikan informasi mengenai kualitas perairan (Cannicci et al., 2009; Kawuri, 2012). Moluska berperan penting dalam aliran alami energi dan nutrisi terutama untuk ikan (Ruswahyuni, 2008).
Pengetahuan mengenai aspek ekologi yang berpengaruh terhadap kehidupan moluska sangat diperlukan untuk pengelolaan yang tepat, sehingga kelangsungan hidup organisme dan kelangsungan produktivitas perairan dapat tetap terjaga. Pengukuran parameter fisika dan kimia dapat menggambarkan kualitas lingkungan. Pengukuran indikator biologi dapat memberikan petunjuk dan evaluasi terjadinya pencemaran. Dampak pencemaran terhadap organisme perairan yaitu menurunnya kelimpahan dan keanekaragaman hayati pada perairan salah satunya adalah komunitas moluska (Zahidin, 2008).

Kajian tentang aspek ekologi moluska yang berada di perairan Pantai Mertasari sangat diperlukan sebagai indikator untuk mengetahui kondisi lingkungan di Pantai Mertasari dengan mengkaji sebaran dan struktur komunitas moluska dan faktor-faktor lingkungan yang dapat mempengaruhi kehidupannya.

\section{Metode Penelitian}

\subsection{Waktu dan Tempat}

Penelitian dilakukan di Perairan Pantai Mertasari Denpasar selama tiga bulan yang dimulai dari Januari-Maret 2017. Penelitian ini bersifat observasi dengan teknik sampling berupa sistematik sampling. Penentuan stasiun penelitian dibagi menjadi dua stasiun pengamatan.

\subsection{Alat dan Bahan}

Alat dan bahan yang digunakan dalam penelitian yaitu transek kuadrat $1 \times 1 \mathrm{~m}^{2}$, DO meter, $\mathrm{pH}$ pen, refractometer, buku identifikasi moluska, aquades, formalin $4 \%$, dan alkohol $70 \%$.

\subsection{Pengambilan sampel}

Pengambilan sampel moluska dilakukan setiap 2 minggu sekali selama dua bulan menggunakan metode transek kuadrat sistematik sampling 1x1 $\mathrm{m}^{2}$ dengan jumlah kuadrat dibagi menjadi 25 ruang yang masing-masing berukuran 0,2 $\mathrm{m} \times 0,2$ m. Pada setiap substasiun ditarik garis transek tegak lurus dari garis pantai sepanjang $50 \mathrm{~m}$ ke arah laut, pada tiap jarak $20 \mathrm{~m}$ diletakkan transek kuadrat. Moluska diamati pada 5 petak kecil (dengan ukuran petak kecil 0,2 $\mathrm{m} \times 0,2 \mathrm{~m}$ ). 


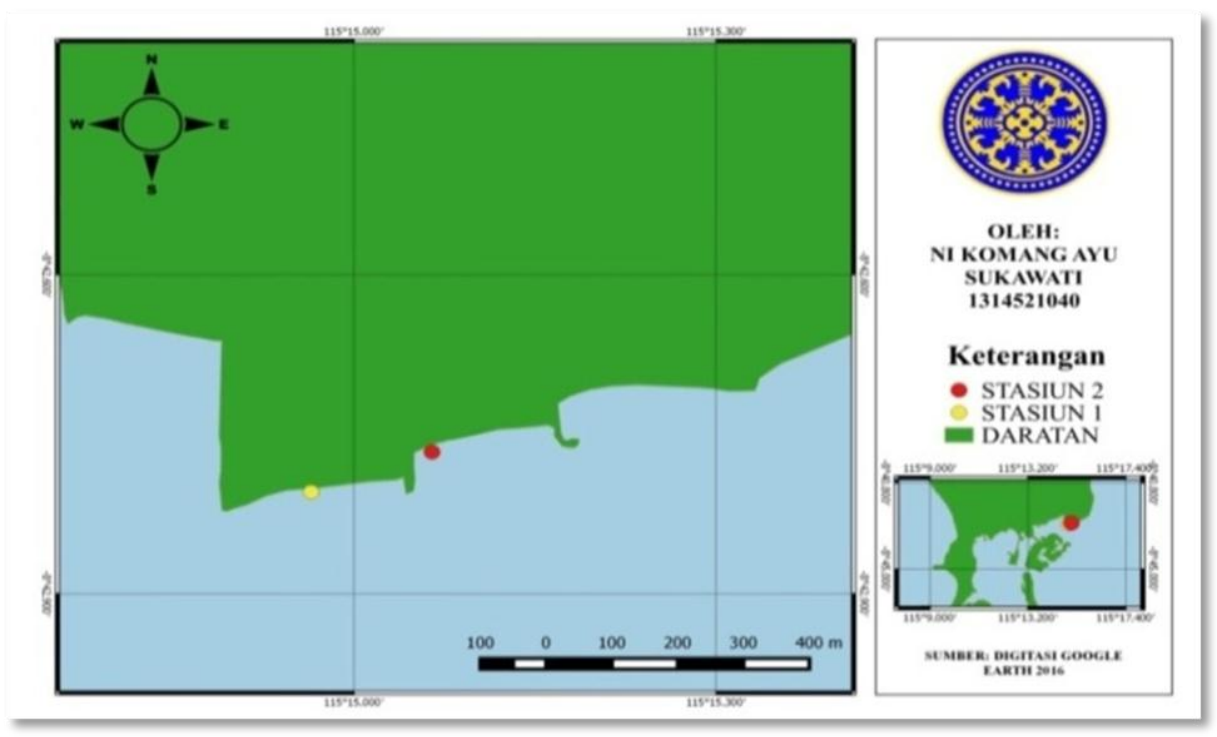

Gambar 1. Lokasi Penelitian di Perairan Pantai Mertasari Kota Denpasar Provinsi Bali

Sampel moluska yang diambil yaitu yang berada pada permukaan sedimen dan di dalam substrat pada 5 petak kecil transek sampai kedalaman $20 \mathrm{~cm}$, kemudian sampel moluska disaring menggunakan saringan. Sampel yang didapat dimasukkan ke dalam plastik dengan diberisi larutan alkohol $70 \%$ dan formalin $4 \%$. Sampel Moluska diidentifikasi hingga tingkat genus dan spesies di Laboratorium. Parameter fisika-kimia perairan yang diukur dalam penelitian ini meliputi oksigen terlarut (DO), $\mathrm{pH}$, suhu dan salinitas.

\subsection{Analisis Data}

\subsubsection{Kelimpahan Jenis}

Rumus dari kelimpahan jenis menurut Brower dan Zar (1977) adalah:

$\mathrm{Di}=\frac{\mathrm{ni}}{\mathrm{A}}$

Di : Kelimpahan jenis ke-i (individu/ $\mathrm{m}^{2}$ )

ni : Jumlah individu jenis ke-i

A : Luas petak pengambilan sampel $\left(\mathrm{m}^{2}\right)$

\subsubsection{Indeks Keanekaragaman Jenis}

Rumus keanekaragaman jenis menurut Poole (1974) adalah:

$\mathrm{H}^{\prime}=-\sum_{\mathrm{i}-1}^{\mathrm{s}}(\mathrm{Pi})\left(\log _{2} \mathrm{Pi}\right)$
$\mathrm{H}^{\prime} \quad$ : Indeks keanekaragaman Shannon-Wiener

$\mathrm{S} \quad$ : Jumlah spesies

$\mathrm{Pi} \quad$ : Proporsi jumlah individu jenis ke-i dengan jumlah individu total sampel

Tabel 1

Tolak Ukur Indeks Keanekaragaman Jenis

\begin{tabular}{cc}
\hline Nilai Total Ukur & Keterangan \\
\hline $\mathrm{H}^{\prime}<1,0$ & Keanekaragaman rendah \\
$1,0<\mathrm{H}^{\prime}<3,322$ & Keanekaragaman sedang \\
$\mathrm{H}^{\prime}>3,322$ & Keanekaragaman tinggi \\
\hline
\end{tabular}

\subsubsection{Indeks Keseragaman}

Rumus indeks keseragaman menurut Krebs (1978) :

$\mathrm{E}=\frac{\mathrm{H}^{\prime}}{\log _{2} \mathrm{~S}}=\frac{\mathrm{H}^{\prime}}{\mathrm{H}_{\mathrm{maks}}}$

E : Indeks keseragaman (Evenness index)

$\mathrm{H}^{\prime} \quad$ : Indeks keanekaragaman Shannon-Wiener

S : Jumlah spesies

Tabel 2

Tolak Ukur Indeks Keseragaman Jenis

\begin{tabular}{cc}
\hline Nilai Total Ukur & Keterangan \\
\hline $\mathrm{E}<0,4$ & Keseragaman rendah \\
$0,4<\mathrm{E}<0,6$ & Keseragaman sedang \\
$\mathrm{E}>0,6$ & Kesseragaman tinggi \\
\hline
\end{tabular}




\subsubsection{Indeks Dominansi}

Rumus indeks dominansi menurut Odum (1993) adalah :

$\mathrm{C}=\sum_{\mathrm{i}=1}^{\mathrm{s}}(\mathrm{Pi})^{2}=\sum_{\mathrm{i}=1}^{\mathrm{s}}\left(\frac{\mathrm{ni}}{\mathrm{N}}\right)^{2}$

C : Indeks dominansi (Index of dominance)

$\mathrm{Ni} \quad$ : Nilai dari setiap spesies (jumlah jenis individu ke-i)

N : Nilai total dari seluruh spesies

$\mathrm{Pi} \quad$ : Perbandingan jumlah individu jenis ke-i dengan jumlah individu total yang telah ditemukan.

Nilai indeks dominansi berkisar antara 0-1 apabila:
$0<\mathrm{C}<0.3$
: Dominansi rendah
$0.3 \leq \mathrm{C} \leq 0.6$
: Dominansi sedang
$0.6<\mathrm{C} \leq 1$
: Dominansi tinggi

\subsubsection{Pola Sebaran Jenis}

Indeks penyebaran menurut Brower dan Zar (1977) digunakan rumus :

$\mathrm{Id}=\mathrm{n} \frac{\left(\sum \mathrm{X}^{2}\right)-\mathrm{N}}{\mathrm{N}(\mathrm{N}-1)}$

Id = Indeks Morisita

$\mathrm{n}=$ Jumlah unit pengambilan contoh

$\mathrm{X}=$ Jumlah Individu pada setiap plot

$\mathrm{N}=$ Jumlah total individu yang diperoleh

Tabel 3

Tolak Ukur Indeks Morisita

\begin{tabular}{clc}
\hline Nilai Total Ukur & \multicolumn{2}{c}{ Keterangan } \\
\hline $\mathrm{Id}<1$ & $\begin{array}{l}\text { Penyebaran individu bersifat } \\
\text { beragam }\end{array}$ \\
$\mathrm{Id}=1$ & $\begin{array}{l}\text { Penyebaran individu bersifat acak } \\
\text { Penyebaran individu bersifat } \\
\text { mengelompok }\end{array}$ \\
\hline
\end{tabular}

\section{Hasil dan Pembahasan}

\subsection{Kelimpahan Jenis Moluska}

Komunitas moluska yang ditemukan di Pantai Mertasari terdiri dari dua kelas yaitu kelas gastropoda sebanyak 25 spesies dan kelas bivalvia sebanyak 6 spesies. Kelimpahan jenis masingmasing spesies moluska berkisar 0,8-11,7 individu $/ \mathrm{m}^{2}$.

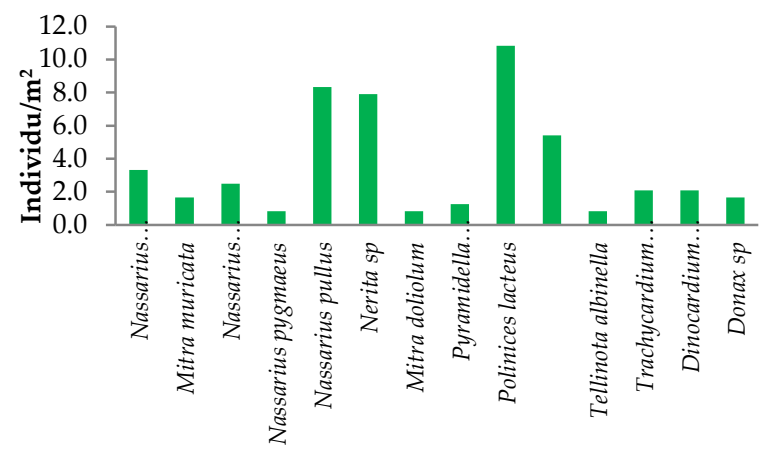

Gambar 2. Kelimpahan Jenis pada Stasiun I

Kelimpahan pada stasiun I yaitu 49,6 individu $/ \mathrm{m}^{2}$ dan pada stasiun II yaitu 75,0 individu $/ \mathrm{m}^{2}$. Kelimpahan total jenis moluska di Pantai Mertasari yaitu 124,5 individu/m². Kelimpahan tersebut lebih tinggi dibandingkan dengan penelitian Pratiwi dan Ernawati (2016) di perairan Nusa Lembongan yang memperoleh hasil kelimpahan jenis moluska berkisar 0,17-1,83 individu $/ \mathrm{m}^{2}$. Hal tersebut berkaitan nilai oksigen terlarut yang rendah di perairan Nusa Lembongan yaitu berkisar antara 2,60-6,90 mg/L. Sedangkan dibandingkan dengan penelitian Laharjana (2016) di perairan Pantai Serangan memperoleh kelimpahan jenis moluska berkisar $0,1-10,0$ ind $/ \mathrm{m}^{2}$, dengan kelimpahan total jenis moluska 106,6 individu $/ \mathrm{m}^{2}$, dimana kelimpahan tersebut tergolong lebih tinggi dibandingkan kelimpahan jenis moluska di perairan Nusa Lembongan. Hal tersebut berkaitan dengan kandungan oksigen terlarut di perairan Pantai Serangan lebih tinggi dibandingkan di perairan Nusa Lembongan yaitu berkisar 4,16-5,26 mg/L. Menurut Syamsurisal (2011), kandungan oksigen terlarut di perairan mempengaruhi jumlah dan jenis makrozoobentos di perairan. Semakin tinggi kadar oksigen terlarut maka jumlah bentos semakin besar.

Kelimpahan moluska pada stasiun I lebih rendah dibandingkan kelimpahan moluska pada stasiun II. Penyebab dari rendahnya kelimpahan moluska di stasiun I dibandingkan pada stasiun II diduga karena perbedaan substrat dasar perairan yaitu substrat berpasir (stasiun I) dan substrat lumpur berpasir (stasiun II). Hal tersebut sesuai dengan pernyataan Riniatsih dan Kusharto (2009), substrat lumpur berpasir merupakan habitat yang 
baik untuk kelangsungan hidup moluska karena kaya kandungan bahan organik.

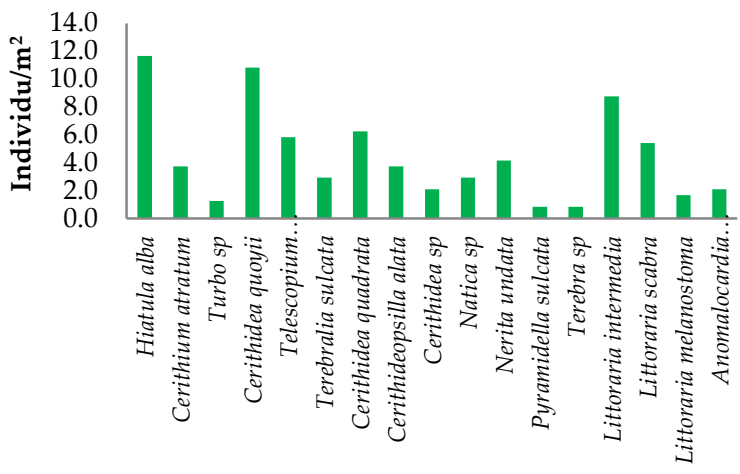

Gambar 3. Kelimpahan Jenis pada Stasiun II

\subsection{Indeks Keanekaragaman, Keseragaman dan Dominansi Moluska}

Nilai indeks keanekaragaman pada stasiun I yaitu 2,29 dan pada stasiun II yaitu 2,58. Berdasarkan nilai tolak ukur indeks keanekaragaman, nilai tersebut menunjukkan bahwa pada stasiun I dan stasiun II memiliki keanekaragaman sedang, hal tersebut menunjukkan kondisi ekosistem di perairan Pantai Mertasari cukup seimbang. Sehingga dapat dikatakan bahwa kondisi lingkungan perairan di Pantai Mertasari tergolong baik. Hasil tersebut berbeda dengan penelitian Wahyuni dkk, (2015) di perairan Bendungan Menaming Kabupaten Rokan Hulu Riau yang memperoleh nilai indeks keanekaragaman 0,551,05. Nilai tersebut lebih rendah dibandingkan dengan keanekaragaman di perairan Pantai Mertasari Kota Denpasar Bali. Keanekaragaman jenis dipengaruhi oleh faktor substrat yang tercemar, kelimpahan sumber makanan dan kondisi dari lingkungan sekitarnya (Rachmawaty, 2011).

Biota laut yang ditemukan di Pantai Mertasari pada stasiun I yaitu cacing Eunice viridis yang berguna untuk makanan moluska karnivora, selain itu terdapat alga chlorophyta yang merupakan makanan untuk moluska herbivora. Ketersediaan sumber makanan di Pantai Mertasari mendukung untuk kelangsungan hidup moluska sehingga keanekaragaman jenisnya cukup tinggi. Nilai indeks keanekaragaman tersebut menunjukkan bahwa tingkat pencemaran di lokasi penelitian tergolong rendah. Hal tersebut sesuai dengan pernyataan Fachrul (2007) dimana perairan yang berkualitas baik memiliki keanekaragaman jenis yang tinggi dan pada perairan yang tercemar memiliki keanekaragaman jenis yang rendah. Jenis-jenis moluska yang ditemukan Wahyuni $d k k$, (2015) di perairan Bendungan Menaming Kabupaten Rokan Hulu Riau lebih sedikit dibandingkan jenis-jenis moluska yang ditemukan di Pantai Mertasari yaitu 3 famili (Ampullaridae, Thiaridae, Pleuroceridae), sedangkan jenis moluska yang ditemukan di perairan Pantai Mertasari yaitu 15 famili (Nassariidae, Mitridae, Neritidae, Pyramidellidae, Naticidae, Tellinidae, Cardiidae, Donacidae, Psammobiidae, Cerithiidae, Turbinidae, Potamididae, Cerithidea, Littorinidae, Veneridae).

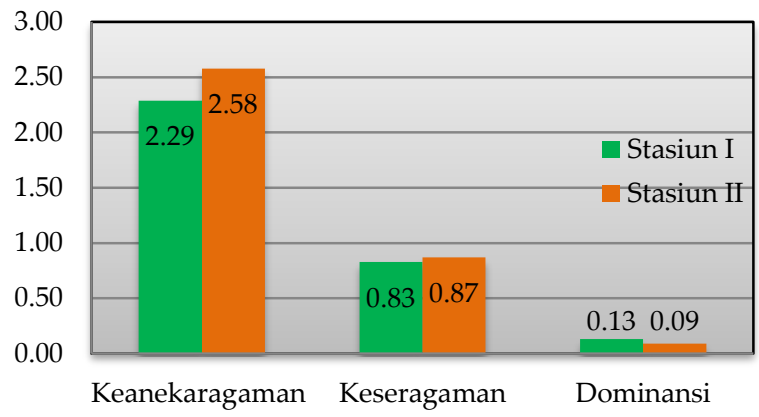

Gambar 5. Grafik Keanekaragaman, Keseragaman dan Dominansi Moluska di Pantai Mertasari

Nilai indeks keseragaman pada stasiun I yaitu 0,83 dan nilai indeks keseragaman stasiun II yaitu 0,87. Berdasarkan tolak ukur indeks keseragaman, nilai tersebut tergolong keseragaman tinggi. Hal tersebut menunjukkan bahwa ekosistem pada stasiun I dan di stasiun II yang merupakan kawasan pariwisata dan kawasan ekosistem mangrove dalam keadaan stabil. Nilai indeks keseragaman tersebut didukung dengan nilai dominansi pada stasiun I dan stasiun II yaitu 0,13 dan 0,09. Nilai tersebut termasuk dominansi rendah, sehingga mengindikasi bahwa jumlah individu tiap spesies relatif sama (seragam) dan tidak ada dominansi pada spesies tertentu.

Keanekaragaman pada stasiun I lebih rendah daripada stasiun II sebaliknya dominansi pada stasiun I lebih tinggi dibandingkan pada stasiun II. Tingginya keanekaragaman pada stasiun II merupakan daerah estuari yang kaya bahan organik. Menurut Dahuri (2003) bahwa pada kawasan estuari, partikel yang di bawa oleh air tawar kaya bahan organik yang digunakan sebagai sumber makanan bagi organisme estuari. Dengan 
adanya sungai yang bermuara di kawasan Pantai Mertasari menyebabkan suplai zat-zat organik tersuspensi yang merupakan makanan utama kerang sangat melimpah. Menurut Pratama (2015), suatu komunitas dengan kondisi lingkungan yang mendukung akan menyebabkan terbentuknya jumlah spesies yang besar dengan kelimpahan yang merata. Hal ini menyebabkan keanekaragaman dalam komunitas tersebut tinggi. Namun, jika dalam suatu komunitas dengan kondisi lingkungan yang tidak mendukung, maka akan cenderung terdiri atas sejumlah kecil spesies yang melimpah, hanya beberapa spesies saja yang dapat bertahan dalam kondisi lingkungan tersebut, sehingga spesies tersebut lebih mendominasi dibandingkan spesies lain yang tidak dapat bertahan.

Tabel 3

Parameter fisika dan kimia perairan pada stasiun I

\begin{tabular}{lccccc}
\hline \multirow{2}{*}{ Parameter } & \multicolumn{3}{c}{ Minggu ke- } & Rata-rata & STDEV \\
\cline { 2 - 4 } & I & II & III & & \\
DO (mg/L) & 6,70 & 4,00 & 5,63 & 5.44 & 1,36 \\
pH & 7,74 & 7,53 & 7,66 & 7.64 & 0,11 \\
Suhu $\left({ }^{\circ} \mathrm{C}\right)$ & 29 & 25,9 & 28,9 & 27.93 & 1,76 \\
Salinitas & 29 & 20 & 27 & 25.33 & 4,73 \\
(ppt) & & & & & \\
\hline
\end{tabular}

Tabel 4

Parameter fisika dan kimia perairan pada stasiun II

\begin{tabular}{|c|c|c|c|c|c|}
\hline \multirow{2}{*}{ Parameter } & \multicolumn{3}{|c|}{ Minggu ke- } & \multirow{2}{*}{ Rata-rata } & \multirow{2}{*}{ STDEV } \\
\hline & I & II & III & & \\
\hline $\mathrm{DO}(\mathrm{mg} / \mathrm{L})$ & 6,0 & 4,7 & 5,36 & 5.35 & 0,65 \\
\hline $\mathrm{pH}$ & 7,4 & 7,49 & 7,39 & 7.43 & 0,06 \\
\hline Suhu $\left({ }^{\circ} \mathrm{C}\right)$ & 27 & 26,5 & 28,6 & 27.37 & 1,10 \\
\hline Salinitas (ppt) & 9 & 11 & 12 & 10.67 & 1,53 \\
\hline
\end{tabular}

Berdasarkan kelimpahan jenis, nilai indeks keanekaragaman, indeks keseragaman dan indeks dominansi tersebut di dukung oleh nilai parameter kualitas air dimana rata-rata nilai oksigen terlarut di Pantai Mertasari di kedua stasiun penelitian berkisar 5,35-5,44 mg/L. Rata-rata nilai $\mathrm{pH}$ di Pantai Mertasari berkisar 7,43-7,64. Nilai $\mathrm{pH}$ tersebut mendukung untuk pertumbuhan moluska. Nilai pH tertinggi yaitu pada stasiun I yang merupakan kawasan pariwisata yaitu 7,64. Suhu di Pantai Mertasari berkisar $27,37^{\circ} \mathrm{C}-27,93^{\circ} \mathrm{C}$. Suhu pada stasiun I yaitu $27,93^{\circ} \mathrm{C}$ dan pada stasiun II yaitu $27,37^{\circ} \mathrm{C}$. Salinitas di Pantai Mertasari berkisar 10,67-25,33 ppt. Pada stasiun I memiliki salinitas 25,33 ppt dan pada stasiun II memiliki salinitas 10,67 ppt, dimana pada stasiun II ini merupakan percampuran air laut dan air tawar (estuari).

Nilai parameter fisika dan kimia perairan pada masing-masing stasiun memiliki nilai yang berbeda, karena masing-masing stasiun memiliki karakteristik habitat yang berbeda.

\subsection{Pola Sebaran Moluska}

Sebaran moluska dapat diketahui dengan perhitungan Indeks Morisita (Id). Pola sebaran moluska pada lokasi penelitian di stasiun I dapat dilihat pada Tabel 5 dan pola sebaran di stasiun II dapat dilihat pada Tabel 6.

\section{Tabel 5}

Pola Sebaran pada Stasiun I

\begin{tabular}{clcl}
\hline No & \multicolumn{1}{c}{ Spesies } & Id & Pola Sebaran \\
\hline 1 & Nassarius pyramidalis & 7.4 & Mengelompok \\
2 & Mitra muricata & 4.1 & Mengelompok \\
3 & Nassarius incrassatus & 6.5 & Mengelompok \\
4 & Nassarius pygmaeus & 5.3 & Mengelompok \\
5 & Nassarius pullus & 3.0 & Mengelompok \\
6 & Nerita sp & 3.1 & Mengelompok \\
7 & Mitra doliolum & 5.3 & Mengelompok \\
8 & Pyramidella suturalis & 6.3 & Mengelompok \\
9 & Polinices lacteus & 2.6 & Mengelompok \\
10 & Cerithium balteatum & 6.2 & Mengelompok \\
11 & Tellinota albinella & 12.0 & Mengelompok \\
12 & Trachycardium subrugosum & 8.0 & Mengelompok \\
13 & Dinocardium robustum & 5.0 & Mengelompok \\
14 & Donax sp & 7.3 & Mengelompok \\
\hline
\end{tabular}

Pola sebaran moluska diketahui dengan menggunakan Indeks Morisita. Pola sebaran moluska di Pantai Mertasari secara umum mengelompok. Pola sebaran mengelompok merupakan pola sebaran paling umum yang terjadi di alam. Kelompok spesies yang memiliki pola sebaran mengelompok sulit untuk berpindahpindah. Sifat individu yang cenderung mengelompok tersebut sebagai akibat menanggapi perubahan cuaca dan musim (Odum, 1993).

Pola sebaran mengelompok berhubungan dengan kondisi lingkungan seperti $\mathrm{DO}, \mathrm{pH}$, suhu dan salinitas yang berfluktuasi. Selain itu disebabkan oleh substrat yang baik dan cocok untuk kehidupan moluska tersebut dan ketersediaan bahan organik yang tinggi. 
Tabel 6

Pola Sebaran pada Stasiun II

\begin{tabular}{clcl}
\hline No & \multicolumn{1}{c}{ Spesies } & Id & Pola Sebaran \\
\hline 1 & Hiatula alba & 2.8 & Mengelompok \\
2 & Cerithium atratum & 4.7 & Mengelompok \\
3 & Turbo sp & 12.0 & Mengelompok \\
4 & Cerithidea quoyii & 2.1 & Mengelompok \\
5 & Telescopium telescopium & 4.2 & Mengelompok \\
6 & Terebralia sulcata & 3.4 & Mengelompok \\
7 & Cerithidea quadrata & 3.9 & Mengelompok \\
8 & Cerithideopsilla alata & 5.0 & Mengelompok \\
9 & Cerithidea sp & 5.0 & Mengelompok \\
10 & Natica sp & 7.0 & Mengelompok \\
11 & Nerita undata & 2.9 & Mengelompok \\
12 & Pyramidella sulcata & 5.3 & Mengelompok \\
13 & Terebra sp & 12.0 & Mengelompok \\
14 & Littoraria intermedia & 2.8 & Mengelompok \\
15 & Littoraria scabra & 5.2 & Mengelompok \\
16 & Littoraria melanostoma & 7.3 & Mengelompok \\
17 & Anomalocardia squamosa & 6.0 & Mengelompok \\
\hline
\end{tabular}

\section{Simpulan}

Moluska yang ditemukan di Pantai Mertasari yaitu 25 jenis moluska dari kelas gastropoda dan 6 jenis moluska dari kelas bivalvia. Kelimpahan moluska di Pantai Mertasari tergolong tinggi yaitu 124,5 individu $/ \mathrm{m}^{2}$. Nilai indeks keanekaragaman berkisar 2,29-2,58 yang tergolong keanekaragaman sedang. Nilai indeks keseragaman berkisar 0,830,87 yang tergolong keseragaman tinggi. Nilai indeks dominansi berkisar 0,09-0,13 yang tergolong dominansi rendah. Pola sebaran moluska di Pantai Mertasari secara umum mengelompok. Parameter fisika dan kimia perairan memiliki kisaran nilai yang mendukung untuk kehidupan moluska. Kondisi lingkungan di Pantai Mertasari cukup baik.

\section{Ucapan terimakasih}

Pada kesempatan ini penulis mengucapkan terima kasih kepada dekan Fakultas Kelautan dan Perikanan Universitas Udayana, pembimbing serta semua pihak yang membantu dalam peneletian.

\section{Daftar Pustaka}

BLH Kota Denpasar. (2015). Status Lingkungan Hidup Daerah (SLHD) Kota Denpasar Tahun 2015. Denpasar, Indonesia: Badan Lingkungan Hidup Kota Denpasar.

Brower, J. E., \& Zar, J. H. (1977). Field and Laboratory Methods for General Ecology. Dubuque, USA: WMc. Brown Company Publisher.
Cannicci, S., Bartolini, F., Dahdouh-Guebas, F., Fratini, S. Litulo, C., Macia, A., Mrabu, E. J., Penha-Lopes, G., \& Paula, J. (2009). Effects of urban wastewater on crab and mollusc assemblages in equatorial and subtropical mangroves of East Africa. Estuarine, Coastal and Shelf Science, 84(3), 305-317.

Cappenberg, H. A. W. (20016). Pengamatan Komunitas Moluska di Perairan Kepulauan Derawan, Kalimantan Timur. Oseanologi dan Limnologi di Indonesia, 1(2), 61-72.

Dahuri, R. (2003). Keanekaragaman Hayati Laut, Aset Pembangunan Berkelanjutan Indonesia. Jakarta, Indonesia: PT. Gramedia Pustaka Umum.

Fachrul, M. F. (2007). Metode Sampling Bioekologi. Jakarta, Indonesia: Penerbit Bumi Aksara.

Kawuri, R. L, Suparjo M. N, \& Suryanti, S. (2012). Kondisi Perairan Berdasarkan Bioindikator Makrozobentos di Sungai Seketak Tembalang Kota Semarang. Jurnal of Menagement of Aquatic Resources, 1(1), 1-7.

Krebs, C. J. (1972). Ecology, the experimental analysis of distribution and abundance. New York, USA: Harper and Row Distribution.

Laharjana, I. K. A. K. (2016). Asosiasi Moluska Benthik dengan Lamun di Perairan Pantai Serangan, Denpasar Bali. [Skripsi]. Badung, Indonesia: Ilmu Kelautan Fakultas Kelautan dan Perikanan Universitas Udayana.

Odum, E. P. (1993). Dasar-Dasar Ekologi. Edisi Ketiga. Yogyakarta, Indonesia: Gadjah Mada University Press.

Poole, R. W. (1974). An Introduction to quantitative ecology. New York, USA: McGraw-Hill.

Pratama, L. S. (2015). Keanekaragaman Kerang (Bivalvia) di Zona Intertidal Teluk Pangpang Kecamatan Muncar Kabupaten Banyuwangi dan Pemanfaatannya Sebagai Buku Suplemen. [Skripsi]. Jember, Indonesia: Fakultas Keguruan Dan Ilmu Pendidikan Universitas Jember.

Pratiwi, M. A., \& Ernawati, N. M. (2016). Analisis Kualitas Air dan Kepadatan Moluska pada Kawasan Ekosistem Mangrove, Nusa Lembongan. Journal of Marine and Aquatic Sciences, 2(2), 67-72.

Rachmawaty, R. (2011). Indeks Keanekaragaman Makrozoobentos Sebagai Bioindikator Tingkat Pencemaran di Muara Sungai Jeneberang. Jurnal Bionature, 12(2), 103-109.

Riniatsih, I., \& Wibowo, E. (2010). Substrat dasar dan parameter oseanografi sebagai penentu keberadaan gastropoda dan bivalvia di Pantai Sluke Kabupaten Rembang. ILMU KELAUTAN: Indonesian Journal of Marine Sciences, 14(1), 50-59.

Ruswahyuni, R. (2008). Struktur Komunitas Makrozobentos yang Berasosiasi dengan Lamun pada Pantai Berpasir. Jurnal Saintek Perikanan, 3(2), 3336. 
Syamsurisal. (2011). Studi Beberapa Indeks Komunitas Makrozoobenthos di Hutan Mangrove Kelurahan Coppo Kabupaten Barru. [skripsi]. Makassar, Indonesia: Program Studi Manajemen Sumberdaya Perairan, Jurusan Perikanan, Fakultas Ilmu Kelautan Dan Perikanan, Universitas Hasanuddin.

Wahyuni, S., Yolanda, R., \& Purnama, A. A. (2015). Struktur Komunitas Gastropoda (Moluska) di
Perairan Bendungan Menaming Kabupaten Rokan Hulu Riau. Jurnal Ilmiah Mahasiswa FKIP Prodi Biologi, 1(1), 1-5.

Zahidin, M. (2008). Kajian Kualitas Air di Muara Sungai Pekalongan Ditinjau Dari Indeks Keanekaragaman Makrozoobenthos dan Indeks Saprobitas Plankton. [Tesis]. Semarang: Program Studi Megister Manajemen Sumber Daya Pantai Universitas Diponegoro.

(C) 2017 by the authors; licensee Udayana University, Indonesia. This article is an open access article distributed under the terms and conditions of the Creative Commons Attribution license (http://creativecommons.org/licenses/by/3.0/). 